\title{
15. Why Are the Stakes So High?: Misconceptions and misunderstandings in China's global quest for energy security
}

ZhongXiang Zhang

\section{Introduction}

China was the world's second-largest carbon emitter behind the United States for years. On the trends of the 1980s and 1990s, the US Energy Information Administration (USEIA 2004) estimated that China's carbon dioxide emissions would not catch up with those of the United States until 2030. China's energy use has surged, however, since the turn of this century, almost doubling between 2000 and 2007. Despite similar rates of real economic growth, the rate of growth in China's energy use during this period was more than twice that of the last two decades of the twentieth century (NBS 2009). As a result, China became the world's largest carbon emitter in 2007, instead of being number two 'until 2030' as estimated as late as 2004.

Confronted with rampant environmental pollution problems and health risks, and rising greenhouse gas emissions and the resulting climate change, the mounting challenge for China is how to keep its energy consumption and carbon dioxide emissions under control while sustaining its rapid economic growth (Zhang 2010a, 2011c). Another enormous challenge that China needs to deal with is a huge increase in its oil imports, which is accompanying its rapid economic growth, and the resulting carbon emissions. This has raised great concern about China's energy security because its rapidly increasing oil imports come mainly from politically unstable regions and are shipped through lengthy sealanes over which China has little influence. Given that global oil markets are very volatile and China's incremental oil demand dwarfs that of any other single country, China's responses to growing energy security concerns have been brought into the spotlight. In this context, China's global quest for resources - in particular, oil and natural gas - has received unprecedented worldwide attention and scrutiny. This is partly because of China's own highprofile, active state diplomacy and its national oil companies' acquisitions in the key exporting regions of oil and natural gas. But, in my view, the stakes are raised unnecessarily high mainly because of the growing politicisation of Chinese energy security as a result of misconceptions and misunderstandings of China's quest for energy security both inside and outside China. Inside China, these relate to the perceived US-led oil blockade against China and China's illusion 
that its investments in oil fields overseas are able to help strengthen its energy security. Western political rhetoric characterises China's efforts to secure energy supplies overseas as a major threat. That rhetoric further intensifies China's mistrust of global oil markets, sparking fears that the energy establishment will seek to deny China's access to the oil it needs for development. Outside China, there are wide misconceptions and misunderstandings of how Chinese policy banks operate and their oil and natural gas-based loans. China's loans are often misrepresented as asking borrowers to sell a fixed quantity of oil to China during the contract period at a predetermined price so that China can capture windfall gains as oil prices rise.

This chapter aims to depoliticise the debate on China's global quest for energy resources and to put discussions on that issue into perspective. To that end, the chapter first categorises the main features of China's energy mix and discusses why energy security in China equates to a large extent to oil security. The chapter then pays special attention to misconceptions and misunderstandings regarding the hypothesised US-led 'oil blockade' against China; the Chinese policy banks and their oil and natural gas-based loans; and the role of chinese investments in oil and gas fields overseas in discussions on China's global quest for energy resources. The chapter ends with some concluding remarks on a more constructive way forward.

\section{Energy Security in the Chinese Context}

China's energy security issues cannot be well understood without a better understanding of its energy mix. This section will categorise the main features of China's energy mix and discuss why energy security in China equates to a large extent to oil security.

\section{Main Reliance on Domestic Energy Resources}

China is self-sufficient in energy. Even in the 1950s when almost all oil was imported, 97 per cent of energy supply was still from domestic sources (Zhang 1998). China's energy balance was also unaffected by the first rise in world oil prices. China is indeed a large energy consumer. With rapid economic growth fuelled by increasing energy consumption, China is now the world's largest energy consumer, with an increasing dependence on imported oil. At the same time, however, China is also the world's largest energy producer. With total domestic primary energy production of 2960 million tonnes of coal equivalent 
$(\mathrm{mtce})^{1}$ and total domestic energy consumption of 3250 mtce in 2010 (Hua 2011), domestic supply provides about 91 per cent of the total energy consumption in China, meaning that overall energy dependence (namely, the ratio of the energy that a country imports to the total it consumes) is about 9 per cent. With a variety of policies and investments in place that will further expand domestic supply capacity, China will continue to rely mainly on domestic supply to meet its growing energy demand in the future.

\section{Heavy Reliance on Coal as a Major Source of Energy}

A country's choice of fuels and technologies depends to a large extent on its resource endowments and their relative prices. China is abundant in coal resources (BP 2011). This abundant supply of coal and its relatively lower price compared with its more environmentally friendly substitutes make China far more reliant on coal for its primary energy needs than any other major economy. As the world's largest coal producer and consumer, China produces and consumes about twice as much coal as the United States, the world number two, and China was responsible for almost half of global coal consumption in 2010 (USEIA 2011a). Coal has accounted for more than two-thirds of China's primary energy consumption for several decades. For a considerable period to come, China's energy mix will remain dominated by coal (IEA 2010, 2011; Zhang 1990).

China displaced Japan as the world's top coal importer in 2011 - a position Japan had held since at least 1975. This raised concerns about whether China can meet its own coal demand. In my view, this is an over-interpretation. China imported 182.4 million tonnes of coal in 2011. That is a very small amount when compared with China's total coal consumption. The move into the position of number-one importer can be attributed to some special factors. On the Japanese side, the Fukushima Daiichi nuclear power plant accident in Japan on 11 March 2011 led to a power shortage. This, combined with strong Japanese currency appreciation, led to slack demand for coking coal as steelmakers curbed production. Moreover, as the magnitude 9.0 earthquake damaged coalfired power plants along the country's north-east coast, this led to a reduction in Japan's imports of thermal coal used for power generation. On the Chinese side, with robust demand for coal for power generation and cement production and rising costs of domestic coal production, foreign coal was particularly attractive to those regions far from domestic coal production bases (Tsukimori 2012).

1 China still uses mtce as its benchmark, whereas the international standard has moved towards oil equivalents (mtoe). Multiplying mtce by 1.43 will convert to mtoe. 


\section{Imports of Natural Gas Set to Rise, but Much Less Concerning than the Oil Situation}

Since 2006 China has been an importer of natural gas. China's imports of natural gas are set to increase as its overall energy consumption rises. China hopes to expand its domestic natural gas output to 150-180 billion cubic metres (bcm) a year by 2020, while imports would amount to $120-150 \mathrm{bcm}$ per annum (Oxford Analytica 2012). Even by then, its gas dependency rate is much less than that of oil. Moreover, the majority of natural gas is used for chemical feedstock and power generation in China. There are a number of alternatives to natural gas for those uses. Furthermore, China's unconventional gas reserves suggest that gas use can expand faster than expected without creating huge new import dependency. According to the US EIA (2011b), China is believed to have the world's third-largest coal-seam gas reserves, and 36 trillion $\mathrm{cu} \mathrm{m}$ of recoverable shale-gas reserves - the largest in the world. ${ }^{2}$ China has significantly increased its expectations for unconventional gas production, announcing in February 2012 a plan to invest RMB116.6 billion to raise coal-seam gas production to $30 \mathrm{bcm}$ per annum by 2015-up from $15 \mathrm{bcm}$ per annum in 2010. Expectations regarding shale-gas output range from 15-30 bcm per annum to 60-100 bcm per annum by 2020 (NDRC et al. 2012; Oxford Analytica 2012). If unconventional gas production meets even the lower bound of expectations, this will significantly cut China's imports of natural gas and its future dependency rate.

China's attempts to achieve a commercial scale of shale-gas production have, however, so far been hindered by the lack of expertise and difficult geology. China's shale-gas is situated in deeper and more difficult terrain than North American formations. Moreover, Chinese companies have struggled to master the hydraulic fracturing and horizontal drilling techniques used to exploit these resources. To that end, Chinese national oil companies (NOCs) establish strategic partnerships with other NOCs and international oil companies (IOCs) to gain technical know-how in areas where Chinese NOCs lack technical expertise. PetroChina, a Hong Kong-listed unit of China National Petroleum Corporation (CNPC), bought in February 2012 a 20 per cent stake in Shell's Groundbirch natural gas development in north-eastern British Columbia, hoping to gain shale-gas experience from Shell (Welsch and Lee 2012). In January 2012, Sinopec signed a deal with Devon Corporation to invest US $\$ 2.2$ billion for a one-third stake in five US shale and oil-and-gas fields controlled by Devon (Xinhua 2012). China National Offshore Oil Corporation (CNOOC) is working with TOTAL in Nigeria's Akpo and Egina deepwater fields (Jiang and Sinton 2011). PetroChina partnered with Shell in March 2010 to acquire a 100 per cent stake of Australian coal-bed methane producer Arrow Energy. The recent flurry of Chinese NOCs'

2 China's own estimate puts its recoverable shale-gas reserves at 25 trillion cu m (NDRC et al. 2012). 
deal-making is more about gaining access to technology than the commodity itself so that Chinese NOCs will be better positioned to explore and develop similar resources (deepwater reserves, coal-bed methane and shale-gas) within China.

Moreover, to achieve the aforementioned ambitious target for shale-gas, from virtually zero in 2012, China allows foreign partners in this sector. In March 2012, Royal Dutch Shell PLC and CNPC signed the first production-sharing contract to explore, develop and produce shale-gas in China. This deal marks a milestone in the development of China's shale-gas reserves and fits in with China's overall strategy to bring technical and operational know-how to the development of its untapped reserves of shale-gas. Under the agreement, Shell will apply its advanced technology, operational expertise and global experience to jointly develop shale-gas with CNPC over a $3500 \mathrm{sq} \mathrm{km}$ area in the FushunYongchuan block in the Sichuan Basin (W. Ma 2012). This pact will serve as a template showing how production-sharing contracts between foreign and domestic companies might work to help China tap this unconventional fuel.

\section{Increasing Dependence on Imported Oil and China's Concerns about the Strait of Malacca}

China's appetite for oil has been soaring over the past two decades. Its oil demand grew from 2.3 million barrels per day (mbpd) in 1990 to $4.4 \mathrm{mbpd}$ in 2000 (IEA 2000). By 2010, China's demand had jumped to 8.9 mbpd (IEA 2011). The IEA (2011) estimates that by 2035, China's oil demand will reach $14.9 \mathrm{mbpd}$, overtaking the United States $(14.5 \mathrm{mbpd})$ as the largest oil consumer in the world.

China was self-sufficient in oil for most of the 60 year history of the People's Republic, but since 1993 it has been a net oil importer. China's economic boom and its stagnating domestic production of oil have produced a growing hunger for imports. As of 2003, China emerged as second only to the United States in terms of oil imports. In 2009, China imported $4.3 \mathrm{mbpd}$, or 51.3 per cent of its demand (IEA 2010). This was the first instance in which China imported more than half of its oil needs. According to China's National Energy Administration, China's oil dependency rate increased further, to 56.5 per cent, in 2011 (Zhong 2012). According to China's General Administration of Customs, China's oil imports cost the country US\$196.7 billion in 2011, accounting for 11.3 per cent of its total import expenditures (J. Ma 2012; Zhong 2012).

China is projected to maintain oil production close to the current level of $4.1 \mathrm{mbpd}$ to 2025 , followed by a steady decline as resource depletion sets in (IEA 2011). As a result its oil imports will continue to soar in the decades 
ahead. The IEA (2011) estimates that by 2035, China will be importing nearly $12.6 \mathrm{mbpd}$ - more than the United States imports today - in order to meet its expected oil demand of $14.9 \mathrm{mbpd}$. This puts China's oil dependency rate at 84.6 per cent in 2035 (IEA 2011). China will thus become far more exposed to the risk of international supply disruptions than it is today. Energy security has risen to the height of importance in its foreign policy, and is becoming what has been called a 'transforming' factor in relations between China and the Middle East, Russia and energy-rich Central Asian, African and Latin American countries (Yi 2005).

Indeed, China's oil dependency rate is already high and increasing; however, this need not be viewed in a solely negative way. As a country's overall trade intensity (defined as a ratio of the sum of imports plus exports to GDP) suggests, the higher ratio means that country is more integrated with the global economy. It does not necessarily suggest increased economic insecurity in that country. Moreover, many large economies have even higher oil dependency rates than China, although China naturally stands out in terms of the sheer quantity of its requirements. Furthermore, China itself experienced complete dependence on foreign oil prior to discoveries of its own reserves in the 1950s. In the post-civil war period China was geopolitically isolated, and it had to import essentially all of its oil. Taking these points together, the oil dependency rate alone is insufficient to determine the true level of energy security/insecurity of a country. To evaluate the energy security of a country properly, this factor has to be combined with other factors, including sources and routes of oil supply. Specifically, we need to look at

- whether oil imports are concentrated on a few source countries-more diversified sources of supply are obviously preferred

- whether the main oil-exporting countries are politically stable

- whether the transport routes for oil imports are considered vulnerable to physical disruption and how much influence the importer has on these transport lanes.

As shown in Figure 15.1, in 1995, China relied mainly on the Middle East and South-East Asia (mainly Indonesia, which alone accounted for nearly one-third of China's total imports) for 82 per cent of its crude-oil imports. The Middle East was - and is - clearly vital. Thus, China will continue to consolidate its base there. In recent years though, China has also turned its attention to the emerging oil and gas fields of Africa. Top Chinese leaders have paid frequent visits to oil-producing countries in the region. This high-profile, goodwillbased energy diplomacy has helped China make remarkable inroads in striking energy deals with oil-rich African countries (Zhang 2007, 2010b). By 2005, this strategy enabled China to significantly diversify its import mix. As shown in 
Figure 15.1, Africa accounted for 30 per cent of China's oil imports in 2005-up from 7 per cent in 1995-while Russia supplied 10 per cent of total imports, up from less than 1 per cent 10 years earlier (Downs 2006).

China became slightly more reliant on the Middle East in 2005 than it had been 10 years ago, with 47 per cent of its imports coming from the Persian Gulf. In addition, because China is now heavily reliant on Africa as well as the Middle East, it now depends more on a single chokepoint - the Strait of Malacca - than it had before, with nearly 77 per cent of its oil imports flowing through the strait. This situation remained unchanged in the following five years: China still imported 78 per cent of its crude from the Middle East and Africa in 2010 (BP 2011; Kennedy 2011).

Figure 15.1 China's Crude-Oil Imports by Region in 1995 (left) and 2005 (right)
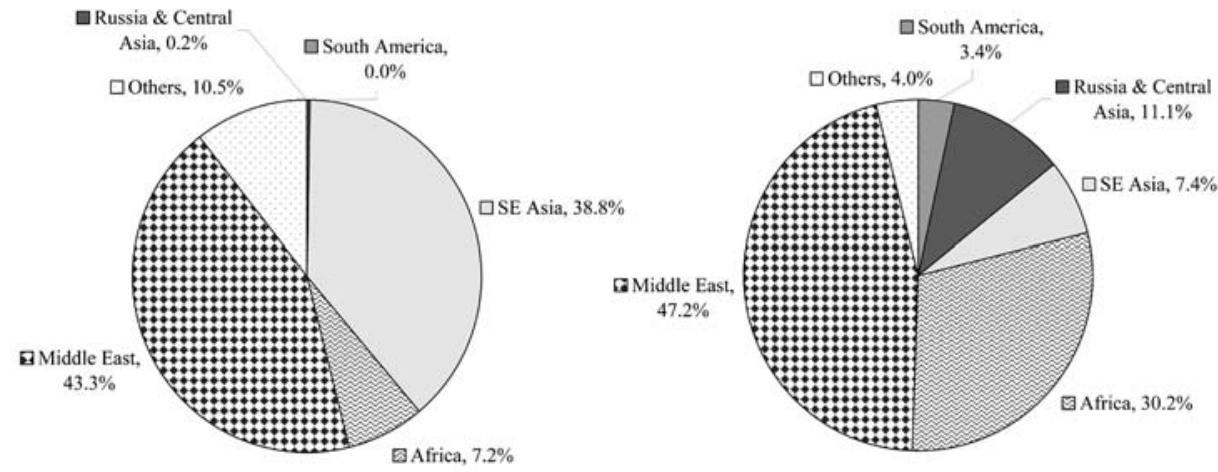

Source: From Chen (2010) and Zhang (2011b).

Foreign trade has become one of the pillars underpinning China's phenomenal economic growth over the past three decades, and oil is intimately related to it. Given that most crude-oil imports from the Middle East and Africa have to pass through the Strait of Malacca, the strait is of immense strategic and economic importance to China's economic and energy security. As a chokepoint, this strait directly affects China's sealane of communications, but China has little direct influence over it. Therefore, China has every reason to be concerned about the safe and smooth passage of its shipments. Beijing feels susceptible to this strategic weakness. Any adverse event in the strait would disrupt its trade flows and particularly oil imports, which could deal a further blow to China's economic development, social stability and military capability (Chen 2010; Zhao 2007).

Clearly, oil poses a unique challenge for China, not only because its oil dependency rate is already high and continues to rise, but also, more importantly, because oil imports come from less politically stable regions and have to be 
shipped to China via routes that are considered vulnerable to physical disruption but which China has little physical sway over. Viewed in this context, energy security in China to a large extent equates to oil security.

\section{Putting China's Global Search for Energy Security into Perspective}

Over the past few years top Chinese leaders have come to view the Strait of Malacca as a strategic vulnerability (Blumenthal 2008; Holmes 2007). In November 2003, President, Hu Jintao, declared that 'certain major powers' were bent on controlling the strait and called for the adoption of new strategies to mitigate the perceived vulnerability. Thereafter, the Chinese press devoted considerable attention to the country's 'Malacca dilemma' (Lanteigne 2008; Storey 2006). The China Youth Daily, a leading Chinese newspaper, declared: 'It is no exaggeration to say that whoever controls the Strait of Malacca will also have a stranglehold on the energy route of China' (Shi 2004).

Given the strategic importance of the Strait of Malacca and China's lack of influence on the waterway, China has made great efforts on both the demand and the supply sides to cope with the perceived 'Malacca dilemma' and to enhance its energy security.

On the demand side, China has taken considerable efforts to control the growth of its demand for energy and oil and thus its demand for oil imports. For the first time, China has incorporated an input indicator as a constraint in its five-year economic plan, requiring that energy use per unit of GDP be cut by 20 per cent during the Eleventh Five-Year Plan period, running from 2006 to 2010. This formal acknowledgment is widely considered to be an important step towards building a 'harmonious society' through 'scientific development'. Just prior to the Copenhagen climate change summit, China further pledged to cut its carbon intensity by 40-45 per cent by 2020 relative to its 2005 levels in order to help reach an international climate change agreement at Copenhagen or beyond (for further discussion, see Zhang 2010a, 2011a, 2011c). Meeting these energy and carbon intensity targets will not only help to limit the growth of China's carbon emissions, but also will reduce China's growing hunger for foreign oil, leave more oil on the market and thus help to stabilise world oil prices.

On the supply side, China has instituted a variety of policies to address its growing dependence on imported oil. The country has made considerable efforts to maintain domestic production close to the current level. In the meantime, China has been making significant efforts to support the expansion of its own NOCs (the so-called 'going-out policy'); to diversify both sources of and routes 
for its oil supply, including setting up a string of refineries in China through joint ventures with partners from energy-rich countries that often come with supply agreements; to develop its own strategic petroleum reserves; and to strengthen its naval capabilities to protect supply lines (Chen 2010; Jiang and Sinton 2011; Kennedy 2011; Wang and Wu 2011; Zhang 2007, 2010b, 2011 b). Clearly, China has resorted to these unilateral and bilateral measures to enhance its energy security and cope with the Malacca dilemma.

In this context, China's global quest for resources - in particular, oil and natural gas - has received unprecedented worldwide attention and scrutiny. This is partly because of China's high-profile energy diplomacy and some debatable issues about the management and operation of Chinese NOCs. In my view, this is mainly because of misconceptions and misunderstandings of China's quest for energy security both inside and outside China. Inside China, these relate to the hypothesised US-led oil blockade against China and the role of Chinese investments in oil fields overseas. Outside China, misconceptions and misunderstandings mainly relate to how Chinese policy banks operate and their oil and natural gas-based loans. The following section seeks to clarify each of these points.

\section{An American-Led Oil Blockade Against China?}

The strategic importance of the Strait of Malacca to China on the one hand and its lack of influence on the waterway on the other have raised concerns about the threat of a US-led oil blockade against China.

As mentioned in the preceding section, China has made great efforts in both the demand and the supply sides to cope with the perceived Malacca dilemma and to enhance its energy security. One of the significant efforts on the supply side is to support the expansion of its own NOCs abroad through the so-called 'going-out policies' and thus to increase the NOCs' overseas oil production. If Chinese NOCs' overseas oil production is to help to improve China's energy security then oil so produced needs to be shipped back to China. But, if the threat of a US-led blockade is a concern then attempts to send Chinese NOCs' equity oil shares back home will face the same blockade problem.

As the sole superpower, the United States is certainly reluctant to accept the rise of China and is wary of any prospective challenge to its hegemony. Geopolitically, the United States has attempted to contain China's increasing global influence. As the United States withdraws from its two long wars in Iraq and Afghanistan and refocuses on the Asia-Pacific region, its 'strategic pivot' to Asia has so far mainly manifested itself in a shoring up of its 'encircling alliances' with the countries on China's periphery (The Economist 2012a). Auctioning a policy that would inhibit the Chinese economy is, however, 
highly unlikely, because the world's two largest economies are too integrated and interdependent for one to fail. It would be a policy of self-immolation. The United States' attempt to influence, but not intervene in, the recent Taiwanese presidential election to avoid instability in the Taiwan Strait clearly supports this view. In the last week or so running up to the election in January 2012, the opposition party's presidential candidate was running neck and neck with the ruling party's nominee. The opposition party was against the 1992 consensus that aims for a peaceful unification of Mainland China and Taiwan and if its candidate had been elected to the presidency, the United States believed the outcome could lead to instability. So, at the last moment, current and former top US officials were in Taiwan, disregarding the opposition party's demand to keep political neutrality, which had been the stance the United States took in previous Taiwanese elections. Instead, these US officials explicitly persuaded the voters to treasure the current stability in cross-strait relations, which was clearly viewed as being to the ruling party's advantage.

Some might take the US-led Trans-Pacific Partnership (TPP) free-trade agreement - essentially a free-trade pact currently under negotiation between the United States, Australia, Brunei, Chile, Malaysia, New Zealand, Peru, Singapore and Vietnam - as a counterargument. But I do not share the view that the United States is using the TPP to isolate China economically. Rather, I think the United States wants to use the TPP to press China to observe the rules of the road on trade and intellectual property. The United States also wants to use the TPP to achieve its major goal of levelling the playing field in which private and state-owned enterprises (SOEs) compete. ${ }^{3}$ This goal reflects serious US frustration with what it sees as the unfair advantages Chinese SOEs have in world trade (Bussey 2012; Davis 2011).

Even if the United States were to attempt a blockade, it would probably not be very successful (Collins and Murray 2008), and would be extremely difficult to operate in practice. If the blockade operations were undertaken close to China, blockading vessels would be vulnerable to attacks from China. In contrast, if the blockade were implemented far from China's shores, it would be extremely difficult to differentiate oil that was bound for China from oil that was bound for other countries, not only because oil carried in a given tanker can be destined for several countries, but also because ownership of the oil within that tanker can easily change during the course of its journey (Kennedy 2011).

3 There is a challenge for the United States to come up with a position on state-owned firms because the US proposal could be used against the US Postal Service, Tennessee Valley Authority and other state-owned or state-controlled entities. The United States also bought a controlling interest in General Motors during the financial crisis. While Democrats on the House Ways and Means Committee in a letter to the White House in June 2011 said that other free-trade agreements had exceptions for 'prudential measures taken to ensure the integrity and stability of the financial system', US trading partners could see an exception of that sort as justifying a variety of aid to their state-owned firms (Davis 2011). 
Taking these points together, it is safe to say that the threat of a US-led oil blockade against China is largely a chimera. If this blockade is unlikely to happen - and even if attempted has a low chance of success - then it seems strange that China's energy security policy should take it as such a serious potential threat.

It is undeniable that Western powers have gained control over the best oil fields available and, as a late entrant to the international oil game, China has little choice but to strike deals with so-called rogue states and to take risks to make acquisitions in oil-rich but politically unstable countries or regions (Zhang 2007, 2010b). That explains why Chinese NOCs are actively bidding for assets in West Africa and Latin America. In my view, however, in their course of action and in the expansion of their overseas business, Chinese NOCs exacerbate the extent of potential disruption to oil supply. And in the name of energy security, Chinese NOCs are complicating China's foreign relations in sensitive regions of the world. This could potentially hijack the Chinese Government's going-out policies, as the NOCs prioritise their own profits but at the potential expense of China's overall national interests.

\section{The Operations of Chinese Policy Banks}

During the 1994 reforms of the financial sector, the Chinese Government created the China Development Bank (CDB) and the Export-Import Bank of China as 'policy banks' (Bräutigam 2009). Their loans would explicitly support the Government's policy objectives. The creation of designated policy banks would theoretically free commercial banks from policy lending and hold them accountable for rational, market-based lending.

The two policy banks provide lines of credit to Chinese NOCs and foreign entities - mainly NOC counterparts - to support international expansion and secure oil or natural gas deals. As shown in Table 15.1, since 2009, CDB has extended lines of credit totalling almost US\$85 billion to national energy companies and government entities in Brazil, Ecuador, Russia, Turkmenistan and Venezuela (Downs 2011a).

There is a widespread perception that the CDB provided these loans exclusively to advance Chinese Government policy objectives without commercial concerns. Contrary to this popular view, the CDB is not a mere puppet of the Chinese Government. It is wholly state owned, but it is not state run.

To be sure, the CDB has a mission to advance the Chinese Government's policy objectives at home and abroad, including securing oil and natural gas supplies, but that mission does not prevent it from pursuing its own agenda to expand its business at home and abroad and pursue profits. In fact, the CDB is successful 
at balancing commercial and policy priorities so that it has high profits and a balance sheet that is even healthier than all the other major Chinese commercial banks. ${ }^{4}$ Its non-performing loans ratio has stood at less than 1 per cent since 2005-lower than that of all other major Chinese commercial banks. It lends at market-based interest rates. The interest rates on the lines of credit totalling US $\$ 45.6$ billion extended to Petrobras, Rosneft and Transneft in 2009 and to Venezuela's Bank of Economic and Social Development in 2010 are all based on the benchmark London Interbank Offered Rate (LIBOR), although the spread over LIBOR in Table 15.1 might be thinner than what a Western bank would require (Downs 2011a).

The CDB has been vocal in mobilising China's massive foreign reserves to support cross-border energy and natural resource deals. Chen Yuan, its Governor, was quoted as saying that investing in energy and minerals was a good way to hedge against a declining dollar and rising commodity prices, and thus served as a medium for shifting China's foreign exchange reserves away from low-yielding financial instruments (Downs 2011b). So the CDB made huge loans to Russia and resource-rich countries in Central Asia, West Africa and Latin America. China's loan commitments of US\$37 billion in 2010 to Latin America were more than those from the World Bank, the Inter-American Development Bank and the US Export-Import Bank combined for that year.

Associated with these loans are the common claims that Chinese loans to Latin America have more favourable terms, impose no policy conditions and have less stringent environmental guidelines than the loans of international financial institutions and Western governments. But Gallagher et al. (2012) find that this is often not the case. They find that the CDB loans carry more stringent terms than World Bank loans. In 2010, the CDB offered Argentina a US\$10 billion loan at 600 basis points above LIBOR. In the same year, the World Bank Group's International Bank for Reconstruction and Development (IBRD) granted

4 There are at least two factors for its success. Under the leadership of its Governor, Chen Yuan, the CDB brought the lender's risk-management system up to global standards, even rejecting loans to projects approved by the powerful National Development and Reform Commission (Downs 2011b). Jacob Frenkel, Chairman of JP Morgan Chase International and a former governor of the Bank of Israel, was quoted as saying that '[e]ven though it is a government arm, it is really treated by the marketplace as a wellmanaged and well-run modern financial institution' (Forsythe and Sanderson 2011). Second, unlike debt issued by other state-owned banks in China, the special financing bonds issued by the CDB are classified at the same level as sovereign debt by the Government. This is considered one of its biggest competitive advantages. Banks that buy the bonds can count them at a zero-risk weighting on their balance sheets. The Chinese Prime Minister, Wen Jiabao, plans to reclassify the CDB as a commercial bank instead of a policy lender so that the $\mathrm{CDB}$ has to compete on an equal footing with other state-owned banks that now have commercial bank status. That means the $\mathrm{CDB}$ would have to pay more to borrow money. With strong resistance from the $\mathrm{CDB}$, the Chinese Government extended its special financial status through the end of 2012 (Forsythe and Sanderson 2011). 
Argentina a US $\$ 30$ million loan with a spread of 85 basis points. In 2009, the CDB gave Brazil a US $\$ 10$ billion loan at 280 basis points. The IBRD gave Brazil a US $\$ 43.4$ million loan in 2000 at a variable spread of $30-55$ basis points.

Table 15.1 China Development Bank's Energy-Backed Loans

\begin{tabular}{|c|c|c|c|c|c|}
\hline & Borrower & $\begin{array}{c}\text { Amount } \\
\text { (US\$billion) }\end{array}$ & $\begin{array}{l}\text { Term } \\
\text { (year) }\end{array}$ & Interest rate & $\begin{array}{l}\text { Oil/gas deliveries } \\
\text { to secure loan** }\end{array}$ \\
\hline 2005 & Rosneft, Russia & $6^{*}$ & 6 & $\begin{array}{l}\text { LIBOR }+3.0 \% \\
(2005) \\
\text { LIBOR }+0.7 \% \\
(2006-10)\end{array}$ & $180 \mathrm{kp} / \mathrm{d}$ \\
\hline 2008 & $\begin{array}{l}\text { BANDES, } \\
\text { Venezuela }\end{array}$ & 4 & 3 & n.a. & $100 \mathrm{kp} / \mathrm{d}$ \\
\hline 2009 & Rosneft, Russia & 15 & 20 & LIBOR + 5.69\% & $180 \mathrm{kp} / \mathrm{d}$ \\
\hline 2009 & Transneft, Russia & 10 & 20 & LIBOR + 5.69\% & $120 \mathrm{kp} / \mathrm{d}$ \\
\hline 2009 & Petrobras, Brazil & 10 & 10 & LIBOR + $2.8 \%$ & $150-200 \mathrm{kp} / \mathrm{d}$ \\
\hline 2009 & $\begin{array}{l}\text { BANDES, } \\
\text { Venezuela }\end{array}$ & 4 & 3 & n.a. & $107-153 \mathrm{kp} / \mathrm{d}$ \\
\hline 2009 & $\begin{array}{l}\text { Turkmengaz, } \\
\text { Turkmenistan }\end{array}$ & 4 & n.a. & n.a. & n.a. \\
\hline 2010 & $\begin{array}{l}\text { BANDES, } \\
\text { Venezuela }\end{array}$ & 20.6 & 10 & LIBOR + 0.5-2.85\% & $200-300 \mathrm{kp} / \mathrm{d}$ \\
\hline 2010 & $\begin{array}{l}\text { Ministry of } \\
\text { Finance, Ecuador }\end{array}$ & 1 & 4 & $6.0 \%$ & $36 \mathrm{kp} / \mathrm{d}$ \\
\hline 2011 & $\begin{array}{l}\text { Turkmengaz, } \\
\text { Turkmenistan }\end{array}$ & 4.1 & n.a. & n.a. & $10 \mathrm{bcm}$ \\
\hline 2011 & $\begin{array}{l}\text { BANDES, } \\
\text { Venezuela }\end{array}$ & 4 & n.a. & n.a. & n.a. \\
\hline 2011 & $\begin{array}{l}\text { Ministry of } \\
\text { Finance, Ecuador }\end{array}$ & 2 & 8 & $6.90 \%$ & $67.58 \mathrm{kp} / \mathrm{d}$ \\
\hline
\end{tabular}

n.a. = not applicable

"includes funds from Export-Import Bank of China

"* $\mathrm{kb} / \mathrm{d}=$ thousand barrels per day

Source: Downs (2011a).

China's Export-Import Bank, in contrast, generally offers lower interest rates than the US Export-Import Bank. This is mainly because Chinese banks package commercial financing and development aid differently than their foreign counterparts. Instead of giving development aid through the CDB, China channels it through China's Export-Import Bank. The IBRD and other development banks offer concessionary interest rates as an official form of development aid, while the CDB does not. Despite the CDB's 'development bank' label, the Chinese bank generally charges borrowers the full cost of finance. 
For this reason, Bräutigam (2009) labels the CDB 'the development bank that doesn't give aid'. It is not surprising, therefore, that the CDB's interest rates are higher (Gallagher et al. 2012).

Given that the CDB offers loans at market-based interest rates on the one hand and that it imposes no policy conditions on the other, to mitigate loan risks, Chinese banks do require equipment purchases and sometimes oil sale agreements with borrowers as a sort of collateral in kind. This method allows China to loan to less creditworthy borrowers. As the CDB founder, Chen Yuan, states, backing loans with oil shipments 'effectively keeps risks to a minimum level' (Forsythe and Sanderson 2011). The risk mitigation of loans-for-oil seems to explain why the CDB was able to offer the US\$20 billion loan to Venezuela at a floating rate of 50-285 basis points over LIBOR - only a fraction of its 935 basis point cost in sovereign debt markets (Gallagher et al. 2012). To date, this kind of lending seems to work well for borrowing countries in which they need less costly Chinese inputs and equipment to develop their own energy, mining, infrastructure, transportation and housing sectors. We will discuss this issue further in the next section.

\section{Loans for Oil and Gas Deals}

Using loan-for-oil and loan-for-gas deals to secure long-term supplies is not a Chinese invention. Japan gave China loans for its oil as early as the 1970s. This type of deal is not new for China and has been used by Chinese NOCs for some time. In 2004, CNPC loaned the Russian oil producer Rosneft US\$6 billion for 180000 barrels per day of oil supplies through 2010 (Downs 201 la). But such deals are dwarfed by the deal with Russia in 2009. China and Russia had been discussing a cross-border pipeline for crude oil since the early 1990s, but were not able to finalise a deal. Leveraging its relative financial strength at a time when most other big economies were in recession, China eventually struck its longawaited mega loan-for-oil deal with Russia on 17 February 2009. Under this longterm deal, the CDB lends US\$25 billion to Rosneft, Russia's biggest oil producer, and Transneft, its oil pipeline operator. In exchange, Russia will provide China with an additional 15 million tonnes of crude oil a year between 2011 and 2030, which represents about 300000 barrels per day for 20 years, or nearly 7 per cent of China's volume of oil imports in 2009, through a new pipeline, which began making commercial deliveries on 1 January 2011. The deal not only provides the two Russian oil companies with much needed credit, it also helps Russia to secure customers and reduce its dependence on Western European customers. Another notable deal is a US\$10 billion loan agreement with the Brazilian stateowned oil giant Petroleo Brasileiro SA, known as Petrobras - the biggest deal in Central and South America. This loan is to help Petrobras develop newly discovered offshore oil reserves, which promise to convert Brazil into a major 
world oil exporter. Under the terms of the 10-year loan from CDB, Petrobras was to supply China Petroleum and Chemical Corporation, known as Sinopec, with 150000 barrels per day in 2009, rising to 200000 barrels per day for another nine years, from 2010 to 2019 (Ma 2009; The Economist 2010).

It should be pointed out that loan-for-oil and loan-for-gas deals are not without risk. Contracts could be voided with a change of government. Resourcerich countries might fail to supply the promised quantities. Moreover, because the oil is not collateral for the loan, if the borrowers threaten to cut off the supply of oil, lenders cannot seize extra oil or oil revenue to compensate for potential losses (Jacob 2010; Jiang and Sinton 2011). Therefore, loan-for-oil and loan-for-gas deals are not the preferred method of the NOCs to gain foreign supplies. Good-quality assets are, however, rarely for sale these days, and even if they were, Chinese NOCs might not be able to fairly win the bids, as foreign governments have blocked many Chinese NOCs' attempts to buy oil fields. Given these constraints, loan-for-oil and loan-for-gas deals serve as a secondbest strategy for China to diversify its oil supply (Arnson and Davidow 2011; Jiang and Sinton 2011; The Economist 2010).

In the midst of the global financial crisis, China further diversified its energy import mix via loan-for-oil and loan-for-gas deals. Chinese state-owned banks made loans worth US $\$ 77$ billion to nine different oil and gas-producing countries in 2009 and 2010, all of which are located outside the Middle East (Jiang and Sinton 2011). Many outside observers explicitly or implicitly assume that these deals grant Chinese NOCs a discount. Under this assumption, borrowers simply send oil to China at a preset price to pay back the loan, and thus might lose out as oil prices rise. This is a misunderstanding of how this kind of deal works, ${ }^{5}$ and is a misreading of the evidence. Chinese NOCs have no bargaining on prices, and all the deals are linked to market prices, not quantities of oil. Russia, Brazil and Venezuela all sell their oil to China at market prices (Downs 2011a; Gallagher et al. 2012; Jiang and Sinton 2011). These market-based arrangements will ensure deliveries of oil, as the temptation to default on supply contracts if the market price were to rise above a negotiated price would be very strong. The difficulties seen in other commodity markets - such as for iron ore - where long-term contracts sit beside spot markets, illustrate this reality.

Chinese NOCs, however, with support from the Chinese Government and backed with Chinese policy banks, did take advantage of stricken foreign companies in the global financial crisis to enable them to reach otherwise

5 In a typical deal involving the $\mathrm{CDB}$, one Chinese NOC and a foreign borrower (say, a foreign oil company), the $\mathrm{CDB}$ provides the loan to the foreign borrower and opens an account to the borrower. Then the Chinese NOC buys the oil from the borrower at market prices and deposits its payments into the borrower's designated account at the CDB. In this way, the foreign borrower is obliged to sell oil to the Chinese NOC, and the CDB is guaranteed to receive payments to repay itself for the loan. 
unlikely deals and receive long-term oil and gas supplies. Moreover, these deals, backed with the CDB's loans, required the borrowers to buy and hire from China to mitigate loan risks, ${ }^{6}$ despite no policy conditions being imposed (Gallagher et al. 2012). The agreement with Petrobras stipulates that US $\$ 3$ billion of the US $\$ 10$ billion loan must be used to purchase oil equipment from China. China's US $\$ 10$ billion loan to Argentina in 2010 is to buy Chinese trains. Thus, this loan is actually a credit line for Chinese railway companies to invest in 10 separate rail projects in Argentina, with the money effectively staying in China. Half of the US\$20.6 billion loan the CDB granted to Venezuela's Bank of Economic and Social Development is denominated in Chinese renminbi, which locks Venezuela into buying Chinese equipment and hiring Chinese firms (De Córdoba 2011; Downs 2011b; Hall 2010). Clearly, in addition to securing oil supplies, these deals also serve the Government's goal of creating new export markets for Chinese companies and at the same time reduce their exposure to default risks and the borrowers' potential for misuse and corruption (Bräutigam 2009). These borrowers find purchase requirements attached to Chinese loans less objectionable because they seek to build up their energy, mining, infrastructure, transportation and housing sectors inexpensively using Chinese inputs and equipment. $^{7}$

\section{Chinese NOCs' Equity Oil Shares}

In the early 2000s, the Chinese Government adopted its so-called going-out policies to help state-owned companies, including Chinese NOCs, to achieve their ambition to grow and build global businesses. Arguably the Government also sees supporting Chinese NOCs to make oil and natural gas mergers and acquisitions (M\&A) overseas as a way to diversify its foreign exchange reserves to higher-yielding assets away from low-yielding financial instruments such as US Treasury Bonds (Downs $2011 \mathrm{~b}$ ). As a result of the going-out policy supported by Chinese policy banks, these NOCs now have equity stakes in production in 20 countries. By the first quarter of 2010, NOCs' overseas equity shares had reached $1.36 \mathrm{mbpd}$ - nearly one-third of China's net imports in 2009 (Jiang and Sinton 2011).

6 Western development loans tend to attach transparency and seniority clauses and reform requirements in an effort to reduce loan risks.

7 This depends on the requirements of the borrowers. Mexico, Colombia and Peru - the traditional borrowers of the World Bank and Inter-American Development Bank-are undertaking projects outside the energy, mining, infrastructure, transportation and housing sectors for which Chinese purchase requirements would be a burden. They find the transparency and reform requirements of Western loans less costly than Chinese equipment. Brazil and Argentina accept Western loans where they find it acceptable to comply with Western standards. At the same time, they take on Chinese oil, mining and railway loans because they are willing to use Chinese inputs and have little objection to the purchase requirements (Gallagher et al. 2012). 
With oil an internationally traded commodity, China's endeavours to expand its global search and production of oil are constantly confronted with the issue of whether this strategy is superior to simply buying oil in open markets because of concerns about Chinese NOCs' overbidding and making investment losses abroad.

The Chinese oil companies have a history of overpaying for equity positions (Balfour 2002). ${ }^{8}$ Because China has viewed paying a higher price than competitors to secure energy resources as more of a national security issue than a pure business decision (Bradsher 2005), such bidding wars between Chinese companies and their rivals have further intensified the tendency of Chinese oil companies to pay far above what competitors offer. Prior to the credit crisis, China had grabbed these deals by overbidding by at least 10 per cent more than its competitor from India did. In January 2006, the CNOOC bought a 45 per cent stake in the Akpo offshore oil and gas field in Nigeria for US\$2.27 billion by outbidding the competitor, India's state-owned Oil and Natural Gas Corp (ONGC), which submitted a bid of US $\$ 2$ billion but withdrew after India's cabinet raised concerns about the risks involved (Aiyar 2006; Masaki 2006). In August 2005, the CNPC paid US $\$ 4.18$ billion to acquire Canadian oil company PetroKazakhstan, making it China's largest foreign acquisition ever at that time (Bradsher 2005). Originally, the CNPC offered US\$3.6 billion. With an Indian consortium (ONGC-Mittal) bid of US $\$ 3.8$ billion, the CNPC hiked its offer to US $\$ 4.18$ billion to secure the deal (Basu 2005).

The financial and credit crises and the decline in global oil demand have turned the oil industry into a buyers' market, however temporarily. Should Chinese oil majors be able to make better M\&A deals than those prior to the credit crisis? On 24 June 2009, Sinopec made a C\$8.27 billion (US\$7.22 billion) takeover bid for the international oil and gas exploration company Addax Petroleum, making it the largest overseas takeover by a Chinese company. The takeover would have given Sinopec access to Addax's stakes in oil fields off the coast of West Africa, as well as in Iraq (Zhang 2010b). The Korea National Oil Corporation also bid for Addax, offering USS\$6.9 billion (The Chosun IIbo 2009). Sinopec offered US $\$ 7.2$ billion to win the deal. So, Sinopec overbid its competitor by only 4.6 per cent - far less than the overbidding of at least 10 per cent it had made in those aforementioned deals prior to the credit crisis. Measured in other ways, however, the story differs. Sinopec's offer is equivalent to US\$34

8 Overpaying for acquisitions does not apply to China alone. Areva, a French state-owned nuclear energy group, is reported to have overpaid in its US\$2.7 billion purchase in 2007 of UraMin, a Canadian start-up firm with mining assets in Namibia, resulting in a huge operating loss for 2011. In the rush to snap up uranium deposits at a time when expectations of a nuclear renaissance caused uranium prices to soar, Areva failed to do enough metallurgical due diligence on UraMin's mines. The reserves in Namibia turned out to be smaller and less easily extractable than expected. This was compounded by a plunging uranium price after the Fukushima nuclear accident, thus further reducing the deposits' value

(The Economist 2012b). 
a barrel of proved reserves and US $\$ 14$ a barrel of proved and probable reserves. The African transaction average in 2007-when the average crude price was similar to the prices in 2009 at the time this deal was made - was US\$14.40 a barrel for proved reserves and US $\$ 9.90$ for proved and probable reserves, respectively. On a proven basis, the 2007 average suggests US\$3.1 billion total value for the deal. Therefore, US $\$ 7.2$ billion implies a 135 per cent premium (Xu 2009). In December 2008, Sinopec paid C $\$ 2.1$ billion to acquire Tanganyika Oil, a Canadian company that owned oil fields in Syria. The 95 per cent takeover marked the first time a Chinese company had almost complete ownership of a formerly North American oil and gas firm. The C $\$ 2.1$ billion deal was initiated when the price of oil was at US $\$ 90$ a barrel. When the price fell to US $\$ 40$ a barrel by December of that year, the offer was generally seen as overpriced. The company still went ahead with the purchase (Vaidyanathan 2012). On 8 October 2011, Sinopec bought Daylight Energy, a Canadian oil and natural gas producer, for about $\mathrm{C} \$ 2.2$ billion in cash. Under the terms of the deal, Sinopec offered C $\$ 10.08$ a share. That is more than double Daylight's closing price of $C \$ 4.59$ on the last trading day and 43.9 per cent above the 60-day weighted average trading price. China's largest refiner paid a very high premium over its share price to fully acquire Daylight Energy (De La Merced 2011).

It is important to note, however, that the higher bid does not always win in a politically charged industry such as energy. CNOOC in 2005 failed to acquire Unocal for US\$18.5 billion, although it topped Chevron's bid of US\$16.4 billion. In the end, Chevron won the deal based on other factors. This overpaying could partly reflect a need to overcome the kinds of political difficulties that hampered Chinese state-owned companies' overseas takeover attempts in recent years. Nevertheless, the Chinese NOCs are more reluctant than in the past to overpay for assets for at least two reasons. First, the Chinese NOCs have moved up technology and project management learning curves that the IOCs have dominated and have become increasingly sophisticated and capable internationally. Second, they have been tightening their premiums by examining the financial returns of their bids. CNOOC has started using a financial metric system that allows it to price its bids more accurately. Now even the larger national oil companies like PetroChina and Sinopec have started to follow the CNOOC's path (Vaidyanathan 2012). A recent study by the International Energy Agency uncovered no evidence of systematic or intentional overpayment associated with recent acquisitions (Jiang and Sinton 2011); however, this is still an issue open to debate, and there is still disagreement. Some American analysts, like Herberg (2012), believe that Chinese NOCs continue to pay significant premiums to acquire overseas assets. Derek Scissors of the conservative Heritage Foundation was also quoted as saying that Chinese companies usually pay 20 to 30 per cent more than other companies to secure assets (Vaidyanathan 2012). The premiums were generally seen as necessary to keep shareholders happy and quell any political concerns 
given anti-China sentiment in certain circles. Eventually, whether assets are worth the premium price in the long run depends on whether and how far the value of oil and gas properties will rise.

Another issue is related to wide concerns about huge losses incurred when investing abroad. A study by China University of Petroleum suggests that China's 'big-three' oil corporations (CNPC, Sinopec and CNOOC) had invested in some 144 overseas projects totalling US $\$ 70$ billion by the end of 2010, but two-thirds of such overseas investments suffered losses (Fu and Lin 2012; Oxford Analytica 2011). Given that these SOEs may cover overseas losses through their access to capital at home, this has created a perception of these SOEs as irresponsible users of state funds.

It can be argued that economic rationales take the back seat if the NOCs' oil production outside China can help to improve China's energy security. The question is then: are the Chinese NOCs' equity oil shares improving China's energy security?

First, as mentioned above, sending Chinese NOCs' equity oil shares home would mean they faced the same US-led oil blockade problem if it were to emerge - even though this author is sceptical about the effectiveness of any blockade, as argued above.

Second, China's oil imports rapidly outpace the equity oil production of the Chinese NOCs and their ability to acquire oil assets and accumulate investments in equity production abroad, so the equity oil strategy is hopelessly inadequate as a critical energy security strategy (Herberg 2012).

Third, it is widely understood that Chinese NOCs' willingness to overpay is to a large extent because these state-owned oil majors are obliged to guarantee China's energy security. There is little evidence, however, to suggest that the Chinese NOCs necessarily send their equity oil production back to China. Instead, the NOCs apparently prefer to let market conditions decide whether it is shipped back to China or whether it is sold to regional or international markets at the best price, as other IOCs do (Jiang and Sinton 2011; Kennedy 2011). Prior to completion of the Kazakhstan-China oil pipeline in 2009, the Chinese equity oil from the Aktobe field in Kazakhstan was transported via the pipeline to Atyrau to be sold on the international market. Even with the new pipeline in operation, some of CNPC's equity oil from Kazakhstan is still not shipped home. CNPC International, the exploration and production arm for CNPC's overseas production, determines whether it is profitable to sell the oil that it produces to China National United Oil Corporation. This CNPC trading company also evaluates whether buying crude oil locally close to the pipeline starting point (Atasu, prior to 2009) is more economical than buying 
crude produced at Aktobe by CNPC's exploration and production subsidiary and transporting it to Atasu (Jiang and Sinton 2011). China's equity production in Venezuela has also not been shipped back to China. This is mainly because it is too costly to do that given the long distance involved, and partly because Venezuelan heavy crude was not compatible with the existing Chinese refining capabilities before PetroChina teamed up with the Venezuelan state-owned oil company, PDVSA, to build a refinery to process this type of crude oil in Jieyang, Guangdong (Jiang and Sinton 2011).

Fourth, the available evidence does not suggest that oil produced from the Chinese NOCs would be either cheaper or more available to Chinese consumers in a supply crisis. Indeed, these NOCs have shown little inclination to grant Chinese customers a discount when prices are high (Kennedy 2011). In fact, the NOCs responded to rising crude oil prices prior to 2008 by reducing supplies of refined products to the Chinese market, resulting in widespread shortages at the pump, since the Government's controls over the prices of oil products did not allow them to pass their rising crude costs on to customers (Downs 2010).

In the meantime, Chinese investments in oil fields overseas do help to pump more oil out of the fields and enlarge the overall availability of oil on the world market. But this is seen as beneficial not only for Chinese consumers but also for other global consumers (Zhang 2007, 2010b). Taking these points together, Chinese NOCs' efforts to secure overseas oil and gas supplies are not a threat to US or Western energy security because Chinese investments in oil fields overseas enlarge the overall availability of oil on the world market. But they do not unambiguously improve China's energy security either because the NOCs do not necessarily send their equity oil production back to China (Herberg 2012; Jiang and Sinton 2011; Kennedy 2011).

\section{Concluding Remarks}

China is the world's largest energy consumer and the world's largest energy producer. China has relied and will continue to rely heavily on domestic energy resources to fuel its economic development. This makes China different from many other large economies. China is a key player on both the demand and the supply sides. Those who hold the 'China energy threat' view and blame Chinese oil demand and imports for high oil prices often tend to neglect this basic fact.

This is not to deny the fact that China is increasingly dependent on imported oil. Indeed, this, combined with its heavy reliance on the Strait of Malacca to ship imported oil to China, poses distinct security challenges for China. Given the strategic importance of the Strait of Malacca and China's limited influence on the waterway, China has taken great efforts on both the demand and the 
supply sides to cope with its perceived Malacca dilemma and to enhance its energy security. China's responses on the demand side are well formulated and justified, but the same cannot be said on the supply side. Some measures - for example, developing its own strategic petroleum reserves - are well taken, but others, such as going-out policies and exacerbation of disruption of supply, are open to debate. They might be considered misguided and not well founded.

Needless to say, NOC expansion is a positive development for the companies themselves. If NOCs' deals improve China's energy security then it is reasonable to allow profitability to be sought as a second priority. If, however, that first condition is not met then the entire strategy is questionable because many NOCs' deals are not justified on economic grounds alone.

China's aggressive global expansion to acquire resources is often perceived as a threat. This is a misreading of the evidence because Chinese NOCs' efforts to secure overseas oil and gas supplies do not threaten US or Western energy security. Most oil produced by Chinese NOCs abroad was sold on international markets, benefiting not only Chinese consumers but also other global consumers. This perceived threat could, however, lead the Chinese NOCs to overpay in deals, and drive up the world prices of resources compared with what would otherwise have been the case. Being aggressive and keeping higher profiles than is strictly necessary, in the name of energy security, the Chinese NOCs are complicating China's foreign relations in sensitive regions of the world and they could hijack the Chinese Government's going-out policies to increase their own profits but at the expense of China's overall national interests.

In the context of discussions of China's energy security, there is a tendency to overestimate potential disruptions to oil supply or take a pessimistic view of the stability of energy trade. This largely reflects mistrust of global oil markets; but evidence suggests that market-based energy contracts are long lasting, prevailing over ideological differences, wars or politically motivated action. Evidence suggests that under commercial contracts the former Soviet Union exported natural gas to Western Europe virtually unimpeded even during the Cold War era; however, brothers can be brought into conflicts if one does not follow market rules. This was clearly reflected by natural gas disputes between Russia and the Ukraine in 2005, despite the fact that the latter was a former Soviet republic and they remain close to each other. Russia attempted to halt the supply of natural gas to the Ukraine because of a disagreement over a payment for its natural gas sold to the Ukraine. Russia supplied the natural gas to the Ukraine at a price of US $\$ 50$ per $1000 \mathrm{cu} \mathrm{m}$ at that time while its gas exported to Western Europe was at a price nearly five times that (Mao 2006). Clearly, the root cause of this dispute was politics because this supply of natural gas was not based on a commercial contract but rather on a political deal. Thus, it should not come as a surprise that one side was not going to stick to the deal when it 
saw changing political conditions on the other side. In this case, Russia viewed the Ukraine's notable trend towards autonomy and political independence away from Russia.

Moreover, the oil embargos led by the Organisation of Petroleum Exporting Countries (OPEC) are most unlikely to be repeated - first, for the sake of OPEC itself. Even if undertaken, they would not be as damaging as in the 1970s because the major energy-consuming economies are much less energy intensive and have diversified their primary energy supply and have built up their emergency oil stockpiles to deal with any physical disruptions to supply. Furthermore, using resources as a political weapon is condemned internationally. Russia has been heavily criticised for its continued differential treatment of the former Soviet republics in terms of the price of its supplied natural gas. It supplies natural gas at a low price to those republics politically close to Russia but at a high price to those politically close to the West. While China denied the embargo threat, it received heavy criticism of its alleged embargo of rare-earth exports to Japan after Japan's arrest of a Chinese trawler captain in the Diaoyu Islands in September 2010.

It thus follows that both China and Western countries need to depoliticise China's global quest for energy security. Western politicians need to recognise that their rhetoric in relation to China's efforts to secure energy supplies overseas - which paints it as a major threat - has done nothing but intensify China's fear that they might seek to deny China's access to the oil it needs for development. China needs to reconsider its stance of distrusting global oil markets and to recognise that reliance on aggressive acquisitions of overseas oil fields and equity oil production has been of little help in strengthening its energy security. Just like other oil importers, China's energy security depends increasingly and deeply on the stability of global oil markets and reliable and growing oil supplies to the market. Thus, China and other major oil-importing countries share profound common interests in maintaining and strengthening the stability of global oil markets and reducing the chance of potential disruptions to oil supply and the resulting damaging oil-price shocks.

\section{Acknowledgments}

I would like to dedicate this chapter to my mother, Guo Xié, who passed away on 3 April 2012. The main ideas of the chapter were presented at the Conference on China Energy Issues in the Twelfth Five Year Plan and Beyond, Singapore, 23-24 February 2012. The chapter has benefited from work in this area from The Australian National University, Brookings Institution, Global Development and Environment Institute and the International Energy Agency. That said, the 
views expressed here are those of the author, and do not reflect the positions of those institutions. The author bears sole responsibility for any errors and omissions that remain.

\section{References}

Aiyar, P., 2006, 'No "great game" between India and China', Asia Times, 13 January, <http://www.atimes.com/atimes/China_Business/HAl3Cb01.html>

Arnson, C. and Davidow, J., 2011, China, Latin America, and the United States: The new triangle, Woodrow Wilson International Center for Scholars, Washington, DC.

Balfour, F., 2002, 'A global shopping spree for the Chinese: Mainland companies are snapping up more overseas assets', Business Week, 18 November, <http://www.businessweek.com/magazine/content/02_46/b3808162.htm>

Basu, I., 2005, 'India discreet, China bold in oil hunt', Asia Times, 29 September, <http://www.atimes.com/atimes/South_Asia/GI29Df01.html>

Blumenthal, D., 2008, 'Concerns with respect to China's energy policy', in G. B. Collins, L. Goldstein, A. S. Erickson and W. S. Murray (eds), China's Energy Strategy: The impact of Beijing's maritime policies, Naval Institute Press, Annapolis, Md, pp. 418-36.

Bradsher, K., 2005, 'Chinese company to buy Kazakh oil interests for $\$ 4$ billion', The New York Times, 22 August.

Bräutigam, D., 2009, The Dragon's Gift: The real story of China in Africa, Oxford University Press, Oxford.

British Petroleum (BP), 2011, BP Statistical Review of World Energy 2011, British Petroleum, London.

Bussey, J., 2012, 'US attacks China Inc.', Wall Street Journal, 3 February.

Chen, S., 2010, 'China's self-extrication from the "Malacca dilemma" and implications', International Journal of Chinese Studies, vol. 1, no. 1, pp. 1-24.

Collins, G. and Murray, W., 2008, 'No oil for the lamps of China?', in G. Collins, L. J. Goldstein and A. S. Erickson (eds), China's Energy Strategy: The impact of Beijing's maritime policies, Naval Institute Press, Annapolis, Md, pp. 387-407.

Davis, B., 2011, 'US targets state firms, eyeing China', Wall Street Journal, 25 October. 
De Córdoba, J., 2011, 'China - oil deal gives Chávez a leg up', Wall Street Journal, 9 November, <http://online.wsj.com/article/SB100014240529702037335045 $77026073413045462 . \mathrm{html}>$

De La Merced, M. J., 2011, 'Sinopec to buy Daylight Energy for \$2.1 billion', The New York Times, 9 October, <http://dealbook.nytimes.com/2011/10/09/ sinopec-to-buy-daylight-energy-for-2-1-billion/>

Downs, E., 2006, China, Foreign Policy Studies Energy Security Series, Brookings Institution, Washington, DC.

Downs, E., 2010, 'China's energy rise', in B. Womack (ed.), China's Rise in Historical Perspective, Rowman \& Littlefield, Lanham, Md.

Downs, E., 2011a, 'China Development Bank's oil loans: pursuing policy-and profit', China Economic Quarterly, vol. 15, no. 4, pp. 43-7.

Downs, E., 2011b, Inside China Inc.: China Development Bank's cross-border energy deals, John L. Thornton China Center Monograph Series No. 3, Brookings Institution, Washington, DC.

Forsythe, M. and Sanderson, H., 2011, 'Financing China costs poised to rise with $\mathrm{CDB}$ losing sovereign-debt status', Bloomberg, 2 May, <http://www. bloomberg.com/news/2011-05-02/financing-china-costs-poised-to-risewith-decision-on-cdb-debt.html>

Fu, M. M. and Lin, X., 2012, 'Overseas investment of Chinese enterprises suffers losses of nearly US $\$ 100$ billion, $70 \%$ of the investment does not make money', China Times, 11 February, <http://finance.sina.com.cn/china/ hgjj/20120211/081311358170.shtml>

Gallagher, K. P., Irwin, A. and Koleski, K., 2012, The New Banks in Town: Chinese finance in Latin America, Inter-American Dialogue, Washington, DC.

Hall, S., 2010, 'China to invest in Argentine railways', Wall Street Journal, 13 July, <http://online.wsj.com/article/SB1000142405274870451890457536 4523811330964.html>

Herberg, M., 2012, China's global quest for resources and implications for the United States, Testimony before the US-China Economic and Security Review Commission, Washington, DC, 26 January, <http://www.uscc.gov/ hearings/2012hearings/written_testimonies/12_01_26/12_1_26_herberg_ testimony.pdf $>$

Holmes, J., 2007, China's energy consumption and opportunities for US-China cooperation to address the effects of China's energy use, Testimony before 
the US-China Economic and Security Review Commission, Washington, DC, 14 June, <http:/www.uscc.gov/hearings/2007hearings/transcripts/ june_14_15/holmes_prepared_remarks.pdf>

Hua, Y., 2011, 'China leads the world in energy production during the 11th five-year period', Sina Finance, 6 January, <http://inance.sina.com. $\mathrm{cn} / \mathrm{g} / 20110106 / 10009212106 . s h t m \mathrm{l}>$

International Energy Agency (IEA), 2000, World Energy Outlook 2000, International Energy Agency, Paris.

International Energy Agency (IEA), 2010, World Energy Outlook 2010, International Energy Agency, Paris.

International Energy Agency (IEA), 2011, World Energy Outlook 2011, International Energy Agency, Paris.

Jacob, J., 2010, 'Ecuador, China sign \$1 billion cash-for-crude loan deal', International Business Times, 1 September, <http://www.ibtimes.com/ articles/48140/20100901/ecuador-china-energy-crude-latinamericapetrochina-petroecuador-opec-loan.htm>

Jiang, J. and Sinton, J., 2011, Overseas investments by Chinese national oil companies: assessing the drivers and impacts, February, Information Paper prepared for the Standing Group for Global Energy Dialogue of the International Energy Agency, Paris.

Kennedy, A., 2011, 'China's petroleum predicament: challenges and opportunities in Beijing's search for energy security', in J. Golley and L. Song (eds), Rising China: Global challenges and opportunities, ANU E Press, Canberra, pp. 121-35.

Lanteigne, M., 2008, 'China's maritime security and the "Malacca dilemma", , Asian Survey, vol. 4, no. 2, pp. 143-61.

Ma, J. T., 2012, The national economy maintained steady and rapid development in 2011, 17 January, National Bureau of Statistics, Beijing, <http://www. stats.gov.cn/tjfx/jdfx/t20120117_402779443.htm>

Ma, W., 2012, 'Shell reaches Chinese shale-gas deal', Wall Street Journal, 21 March.

Ma, Y. D., 2009, 'China and Brazil signed US\$10 billion loan-for-oil for a period of 10 years', Oriental Morning Post, 20 May, <http://www.dfdaily.com/ node2/node23/node220/userobjectlail69877.shtml $>$

Mao, Y. S., 2006, 'Politics vs market', China Security, no. 3, pp. 106-15. 
Masaki, H., 2006, 'Japan takes on China in Africa', Asia Times, 15 August, <http://www.atimes.com/atimes/Japan/HH15Dh01.html>

National Bureau of Statistics of China (NBS), 2009, China Statistical Yearbook 2009, China Statistics Press, Beijing.

National Development and Reform Commission (NDRC), Ministry of Finance, Ministry of Land and Resources and National Energy Administration, 2012, Development Plan for Shale Gas, 13 March, National Development and Reform Commission, Ministry of Finance, Ministry of Land and Resources and National Energy Administration, Beijing, <http://zfxxgk.nea.gov.cn/ auto86/201203/P020120316383507834234.pdf>

Oxford Analytica, 2011, 'China: state firms face scrutiny for overseas losses', Oxford Analytica, 20 October.

Oxford Analytica, 2012, 'China: gas consumption set to soar', Oxford Analytica, 7 February.

Shi, H. T., 2004, 'China's "Malacca dilemma"', China Youth Daily, 15 June, <http://zqb.cyol.com/content/2004-06/15/content_888233.htm>

Storey, I., 2006, 'China's "Malacca dilemma"', China Brief, vol. 6, no. 8 (12 April), $<$ http://www.jamestown.org/single/?no_cache $=1 \&$ tx_ttnews $\% 5$ Btt_ news $\% 5 \mathrm{D}=31575>$

The Chosun IIbo, 2009, 'South Korea fought against China for natural resources despite repeated losses', IFeng, 10 August, <http://finance.ifeng.com/news/ hqcj/20090811/1071120.shtml>

The Economist, 2010, 'Brazil/China economy: deeper inroads - Latin America', The Economist, 16 August, <http://latinamerica.economist.com/news/ brazilchina-economy-deeper-inroads/200>

The Economist, 2012a, 'Lexington: buttering-up and scolding', The Economist, 18 February, p. 36.

The Economist, 2012b, 'Nuclear energy in France: fallout', The Economist, 18 February, p. 67.

Tsukimori, O., 2012, 'China overtakes Japan as world's top coal importer', Reuters, 26 January, <http://www.reuters.com/article/2012/01/26/us-coalchina-japan-idUSTRE80P08R20120126>

United States Energy Information Administration (USEIA), 2004, International Energy Outlook 2004, Energy Information Administration, Washington, DC. 
United States Energy Information Administration (USEIA), 2011 a, International Energy Outlook 2011, DOE/EIA-0484(2011), Energy Information Administration, Washington, DC, <http://205.254.135.24/forecasts/ieo/ pdf/0484(2011).pdf>

United States Energy Information Administration (USEIA), 2011b, World Shale Gas Resources: An initial assessment of 14 regions outside the United States, Energy Information Administration, Washington, DC, <http://www.eia. gov/analysis/studies/worldshalegas/pdf/fullreport.pdf>

Vaidyanathan, G., 2012, 'China: with energy investments rising, vice president heads to US', Greenwire, 14 February.

Wang, X. and Wu, P., 2011, 'China's strategic oil reserves in 2020 will increase to about 85 million tons', China Economic Weekly, 18 January, <http://news. sina.com.cn/c/sd/2011-01-18/001821830415.shtml>

Welsch, E. and Lee, Y., 2012, 'China fuels its global energy supply', Wall Street Journal, 3 February.

Xinhua, 2012, 'Sinopec buys shale interest from Devon for US\$2.2b', Xinhua, 4 January, <http://www.china.org.cn/business/2012-01/04/ content_24316460.htm>

$\mathrm{Xu}, \mathrm{J} ., 2009$, 'Is China Inc. overpaying in its merger deals?', Wall Street Journal, 25 June, <http://blogs.wsj.com/deals/2009/06/25/is-china-inc-overpayingin-its-merger-deals/>

Yi, X., 2005, 'Chinese foreign policy in transition: understanding China's "peaceful development", Journal of East Asian Affairs, vol. 19, no. 1, pp. $74-112$.

Zhang, Z. X., 1990, Evolution of Future Energy Demands and $\mathrm{CO}_{2}$ Emissions up to the Year 2030 in China, ECN-I--91-038, The Energy Research Centre of the Netherlands, The Hague.

Zhang, Z. X., 1998, The Economics of Energy Policy in China: Implications for global climate change, New Horizons in Environmental Economics Series, Edward Elgar, Cheltenham, UK.

Zhang, Z. X., 2007, 'China's hunt for oil in Africa in perspective', Energy and Environment, vol. 18, no. 1, pp. 87-92.

Zhang, Z. X., 2010a, 'China in the transition to a low-carbon economy', Energy Policy, vol. 38, pp. 6638-53. 
Zhang, Z. X., 2010b, 'Energy policy in China in the transition to a low-carbon economy', in F. Fesharaki, N. Y. Kim and Y. H. Kim (eds), Fossil Fuels to Green Energy: Policy schemes in transition for the North Pacific, Korean Energy Economics Institute Press, Seoul, pp. 176-225.

Zhang, Z. X., 201la, 'Assessing China's carbon intensity pledge for 2020: stringency and credibility issues and their implications', Environmental Economics and Policy Studies, vol. 13, no. 3, pp. 219-35.

Zhang, Z. X., 2011b, 'China's energy security, the Malacca dilemma and responses', Energy Policy, vol. 39, pp. 7612-15.

Zhang, Z. X., 2011c, Energy and Environmental Policy in China: Towards a lowcarbon economy, New Horizons in Environmental Economics Series, Edward Elgar, Cheltenham, UK.

Zhao, H., 2007, 'Rethinking the Malacca dilemma and China's energy security', Contemporary International Relations, no. 6, pp. 36-42.

Zhong, J. J., 2012, 'Crude oil imports rose by 6\% year-on-year, dependence rate reached $56.5 \%$ in 2011', China News Net, 13 January, <http://finance. chinanews.com/ny/2012/01-13/3601502.shtml> 